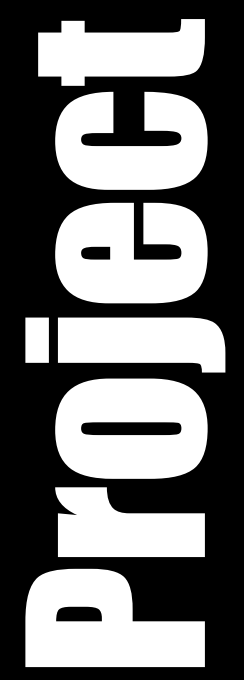

\title{
CAN AIR MOBILITY COMMAND MEET NEW BUILDING PARTNERSHIP CAPACITY OBJECTIVES?
}

\author{
BY \\ COLONEL KONRAD J. KLAUSNER \\ United States Air Force
}

DISTRIBUTION STATEMENT A:

Approved for Public Release.

Distribution is Unlimited.

\section{USAWC CLASS OF 2011}

This SRP is submitted in partial fulfillment of the requirements of the Master of Strategic Studies Degree. The views expressed in this student academic research paper are those of the author and do not reflect the official policy or position of the Department of the Army, Department of Defense, or the U.S. Government.

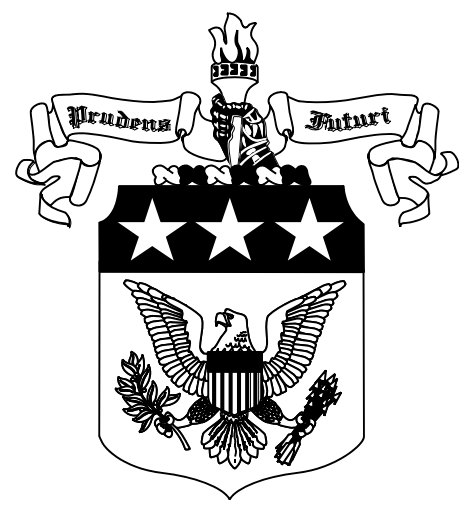


The U.S. Army War College is accredited by the Commission on Higher Education of the Middle State Association of Colleges and Schools, 3624 Market Street, Philadelphia, PA 19104, (215) 662-5606. The Commission on Higher Education is an institutional accrediting agency recognized by the U.S. Secretary of Education and the Council for Higher Education Accreditation. 


\section{REPORT DOCUMENTATION PAGE}

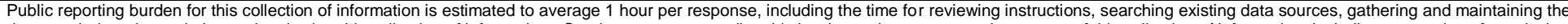

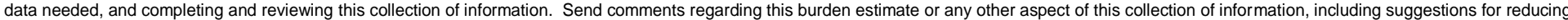

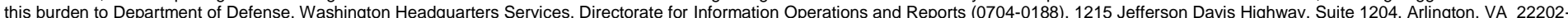

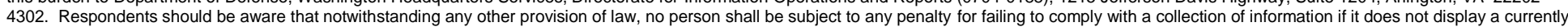
valid OMB control number. PLEASE DO NOT RETURN YOUR FORM TO THE ABOVE ADDRESS.

\begin{tabular}{l|l|l} 
1. REPORT DATE (DD-MM- $Y Y Y Y)$ & 2. REPORT TYPE & 3. DATES COVERED (FrOm - To)
\end{tabular}

24-03-2011 $\quad$ Strategy Research Project

4. TITLE AND SUBTITLE

Can Air Mobility Command Meet New Building Partnership

Capacity Objectives?

12 Jul $10-24 \operatorname{Mar} 11$

5a. CONTRACT NUMBER

5b. GRANT NUMBER

5c. PROGRAM ELEMENT NUMBER

6. AUTHOR(S)

Colonel Konrad J. Klausner

5d. PROJECT NUMBER

5e. TASK NUMBER

5f. WORK UNIT NUMBER

7. PERFORMING ORGANIZATION NAME(S) AND ADDRESS(ES)

8. PERFORMING ORGANIZATION REPORT NUMBER

Colonel Timothy D. Brown

Department of Military Strategy, Planning, and Operations

9. SPONSORING / MONITORING AGENCY NAME(S) AND ADDRESS(ES)

10. SPONSOR/MONITOR'S ACRONYM(S)

U.S. Army War College

122 Forbes Ave.

Carlisle, PA 17013

11. SPONSOR/MONITOR'S REPORT

NUMBER(S)

12. DISTRIBUTION / AVAILABILITY STATEMENT

Distribution A: Unlimited

13. SUPPLEMENTARY NOTES

\section{ABSTRACT}

The 2006 National Security Strategy and subsequent Quadrennial Defense Review called for engagement with nations to build partnerships and the capacities of the partner nations. Headquarters Air Force tasked Air Mobility Command, as lead command for Mobility Air Forces (MAF), to implement the Air Force concept of employment for the new MAF Building Partnerships and Building Partnership Capacity mission. This paper first identifies background information that necessitated the creation of Air Mobility Command's building partnership capacity forces, explores HAF and AMC BP/BPC objectives, examines funding for the new program, explains the various authorities and appropriations for BP/BPC, and evaluates risks and roadblocks to success. Additionally, this paper draws the conclusion that due to funding constraints, manpower challenges, and accelerated growth in building partnerships (BP) requirements, the successful employment of Air Mobility Command's BPC forces may be in jeopardy. Finally, the paper offers five recommendations to address the funding and implementation challenges.

15. SUBJECT TERMS

Light Mobility Aircraft, CRG, CRG AA, Mobility Advisory Group

\begin{tabular}{|c|c|c|c|c|c|}
\hline \multicolumn{3}{|c|}{ 16. SECURITY CLASSIFICATION OF: } & \multirow{2}{*}{$\begin{array}{l}\text { 17. LIMITATION } \\
\text { OF ABSTRACT }\end{array}$} & \multirow{2}{*}{$\begin{array}{l}\text { 18. NUMBER } \\
\text { OF PAGES }\end{array}$} & 19a. NAME OF RESPONSIBLE PERSON \\
\hline $\begin{array}{l}\text { a. REPORT } \\
\text { Unclassified }\end{array}$ & $\begin{array}{l}\text { b. ABSTRACT } \\
\text { Unclassified }\end{array}$ & $\begin{array}{l}\text { c. THIS PAGE } \\
\text { Unclassified }\end{array}$ & & & $\begin{array}{l}\text { 19b. TELEPHONE NUMBER (include area } \\
\text { code) }\end{array}$ \\
\hline
\end{tabular}

Standard Form 298 (Rev. 8-98)

Prescribed by ANSI Std. Z39.18 



\title{
CAN AIR MOBILITY COMMAND MEET NEW BUILDING PARTNERSHIP CAPACITY OBJECTIVES?
}

\author{
by \\ Colonel Konrad J. Klausner \\ United States Air Force \\ Colonel Timothy D. Brown \\ Project Adviser
}

This SRP is submitted in partial fulfillment of the requirements of the Master of Strategic Studies Degree. The U.S. Army War College is accredited by the Commission on Higher Education of the Middle States Association of Colleges and Schools, 3624 Market Street, Philadelphia, PA 19104, (215) 662-5606. The Commission on Higher Education is an institutional accrediting agency recognized by the U.S. Secretary of Education and the Council for Higher Education Accreditation.

The views expressed in this student academic research paper are those of the author and do not reflect the official policy or position of the Department of the Army, Department of Defense, or the U.S. Government. 



\section{ABSTRACT}

AUTHOR: $\quad$ Colonel Konrad J. Klausner

TITLE: $\quad$ Can Air Mobility Command Meet New Building Partnership Capacity Objectives?

FORMAT: $\quad$ Strategy Research Project

DATE:

24 March 2011 WORD COUNT: 5,259

PAGES: 28

KEY TERMS: $\quad$ Light Mobility Aircraft, CRG, CRG AA, Mobility Advisory Group CLASSIFICATION: Unclassified

The 2006 National Security Strategy and subsequent Quadrennial Defense Review called for engagement with nations to build partnerships and the capacities of the partner nations. Headquarters Air Force tasked Air Mobility Command, as lead command for Mobility Air Forces (MAF), to implement the Air Force concept of employment for the new MAF Building Partnerships and Building Partnership Capacity mission. This paper first identifies background information that necessitated the creation of Air Mobility Command's building partnership capacity forces, explores HAF and $\mathrm{AMC} \mathrm{BP} / \mathrm{BPC}$ objectives, examines funding for the new program, explains the various authorities and appropriations for BP/BPC, and evaluates risks and roadblocks to success. Additionally, this paper draws the conclusion that due to funding constraints, manpower challenges, and accelerated growth in building partnerships (BP) requirements, the successful employment of Air Mobility Command's BPC forces may be in jeopardy. Finally, the paper offers five recommendations to address the funding and implementation challenges. 



\section{CAN AIR MOBILITY COMMAND MEET NEW BUILDING PARTNERSHIP CAPACITY OBJECTIVES?}

...there is little of lasting consequence that we can accomplish in the world without the sustained cooperation of our allies and partners.

$$
\text { -President George W. Bush }{ }^{1}
$$

America's strategic leaders recognize the nation cannot achieve its national security strategy objectives unilaterally. Both the 2006 and 2010 U.S. National Security Strategy recognize that in order to meet national objectives and advance national interests, the United States will need to partner with nations around the world. The 2006 National Security Strategy (NSS) states, "we must lay the foundations and build the institutions that our country needs to meet the challenges we face....The United States must...strengthen alliances to defeat global terrorism and work to prevent attacks against us and our friends." ${ }^{2}$ Despite a change in the Presidential Administration in 2008 , the current administration echoed the former by continuing the theme of international cooperation. The 2010 NSS furthers the international partnership theme by saying, "The starting point for...collective action will be our engagement with other countries." $\quad$ To further define the nation's intent, this strategy states, "Our military will continue strengthening its capacity to partner with foreign counterparts, train and assist security forces, and pursue military-to-military ties with a broad range of governments."4

The Department of Defense, in the 2006 Building Partnership Capacity (BPC) Quadrennial Defense Review Execution Roadmap, called for the services to breed more culturally savvy leaders and operators, enabling personnel to comfortably work side-by-side with international organizations and non-governmental organizations as 
well as local groups in foreign lands to further U.S. national and partner nation interests, using personal relationships rather than kinetic military action. ${ }^{5}$ As part of this call, the U.S. Air Force created its Global Partnership Strategy and subsequently realigned Mobility Air Forces (MAF) to meet part of the BPC Roadmap objectives. As the executive agent for the MAF, Air Mobility Command (AMC) developed the Concept of Employment (CONEMP) to execute Headquarters Air Force (HAF) direction. However, with a growing national debt and forecasted budget cuts for the Department of Defense, can Air Mobility Command meet future AMC Global Reach Laydown commitments while adding Building Partnerships (BP) and Building Partnership Capacity taskings?

This paper first identifies background information that necessitated the creation of Air Mobility Command's building partnership capacity forces, explores HAF and AMC $\mathrm{BP} / \mathrm{BPC}$ objectives, examines funding for the new program, explains the various authorities and appropriations for BP/BPC, and evaluates risks and roadblocks to success. Additionally, this paper draws the conclusion that due to funding constraints, manpower challenges, and accelerated growth in Building Partnerships requirements, the successful employment of Air Mobility Command's BPC forces may be in jeopardy. Finally, the paper offers five recommendations to address the funding and implementation challenges.

\section{Background}

Air Force Doctrine Document 3-20, Building Partnerships, defines building partnerships as the ability to set the conditions for interaction with partner, competitor or adversary leaders, military forces, or relevant populations by developing and presenting information and conducting activities to affect their perceptions, will, behavior, and 
capabilities. This "partnership" is a key element in assuring our allies and partners, dissuading potential adversaries, deterring aggression, countering coercion, and ensuring access to critical locations while assisting the United States in forming coalitions to defeat adversaries, real or potential. ${ }^{6}$

Despite the U.S. Government and Armed Forces having a long history of supporting other countries through various security assistance programs, the path to a coherent national and military strategy for BP and BPC has recently taken shape since 9/11. Secretary of State Hillary Clinton recounted multiple interagency efforts and successes in an article she penned in Foreign Affairs, claiming, "collaboration among American civilians from across the government has reached new levels" ${ }^{7}$ As an example, due to Haitian government collapse, U.S. Government support for the 2010 Haitian earthquake relief effort required the expertise and assistance from over five Departments including Defense, State, Homeland Security, Transportation, and Health and Human Services. ${ }^{8,9}$ Recognizing the U.S. Government goal of full, interagency operations, U.S. Africa Command, Department of Transportation, and Department of State continue efforts to cross-educate one another in developing interagency plans for security assistance.

The U.S. Air Force adopted BP as a core function and continues to incrementally grow the capability. Following the 2006 NSS, the U.S. Department of Defense (DoD) published its 2006 Quadrennial Defense Review (QDR) and the Building Partnership Capacity (BPC) QDR Execution Roadmap. The DoD BPC Roadmap "facilitates transition to QDR implementation by providing strategic direction and a plan of action for

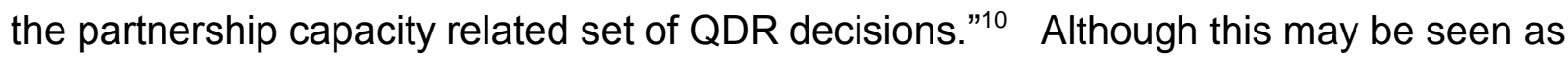


common sense or intuitive, the U.S. Presidents' declarations of strategy and follow-on DoD guidance within the QDR and BPC Roadmap demonstrated the United States' strategic leaders' focus on national security and its relationship with building partnerships by providing an assessment of the future and a broad vision to achieve its goals.

During Operations ENDURING and IRAQI FREEDOM, the Department of Defense recognized it needed to strategically rebalance itself to achieve the objectives described in both the 2006 and 2010 National Security Strategy. ${ }^{11}$ A large part of this strategy involves partnering with foreign nations to either assist in strengthening their militaries for internal defense or to build relationships to ensure access in time of future need. Chairman of the Joint Chiefs of Staff, Admiral Michael Mullen, in the 2011 National Military Strategy weaves building partnerships into the strategy as one of three recurring themes in achieving the strategy objectives. ${ }^{12}$ The Air Force Chief of Staff, General Norton Schwartz, provided strategic change and realignment to the Air Force by setting it on a new path to win the current wars and prevent future wars, which included a broader partnership component. Schwartz looked holistically at the Air Force's future capabilities to meet national security objectives. He needed to break existing Special Operations, Combat, and Mobility Air Forces stovepipes and change the Air Force's direction to a more combined air arms effort.

Understanding the harsh realities of tighter future Air Force budgets, Schwartz launched two efforts to realign the MAF. He commissioned a Contingency Response (CR) Forces requirements review and the Irregular Warfare Tiger Team (IWTT). The CR requirements review looked across Geographic Combatant Commander (GCC) 
lines to eliminate redundancy of CR capability and provide manpower and fiscal resources to posture the MAF for potential future mission change. The irregular warfare team looked across the spectrum of Air Force functions to determine where or how it, and ultimately the MAF, might contribute to the Defense Department's vision of building partnerships and capacity for airlift operations. This was not an easy task as the stovepipes within the Air Force and within the GCCs guardedly attempted to retain capability to meet their missions. The IWTT and HQ AMC determined, after visiting each GCC and through a Capability Based Assessment, that "a clear capability gap exists for [affordable and sustainable] light mobility" for partner nations. ${ }^{13}$ Applying the vision set forth by the Chief, the Air Force moved forward with a proposal having minimal manpower growth for the MAF while shifting existing CR capability to the new mission.

General Schwartz decided to support the recommended MAF "way ahead" that included a reorganization of the AMC Contingency Response Wings (CRWs) and acquisition of a new training aircraft known as the Light Mobility Aircraft (LiMA). The CRWs reorganized in the summer of 2010 , thereby paving the way to shift manpower within the wings to the new BP/BPC mission. The next task will be explaining this new MAF strategy to Congress for FY2011 funding to implement the new program. The Air Force clearly linked the new capability with the National Security Strategy and requested the funding necessary to purchase and program the new training aircraft capability. As a steward of the DoD budget, General Schwartz fully understood the Air Force must retain flexibility in its responsibility to balance both combat capabilities with this new partnership vision. General Schwartz stated in his decision to move forward 
with the LiMA, "the idea here is to work our way into this - start small and see where it takes us." ${ }^{14}$ The Air Force FY11 budget overview details a funding request for research, development, and procurement of 15 LiMAs. ${ }^{15}$

General Schwartz's staff produced several documents forwarding his strategy for the building partnership and partnership capacity programs. Under the direction of General Schwartz, Air Force staffs generated the Air Force Global Partnership Strategy (AFGPS), Institutionalizing Building Partnership into Contingency Response Forces (CRF) CONEMP, and a new doctrine document AFDD 3-20, Building Partnerships (Draft). Subsequently, AMC produced a CONEMP to provide further guidance to the Command. Each of these documents explains the Chief's vision, priorities, alignment, and need for change. The purpose of the BP CONEMP is to describe:

how CRF will execute actions to support...the USG in achieving desired....BP objectives.... Though the majority of descriptions is applicable to leveraging agile combat support skill sets, it is not meant to discount... [other] missions of the CRFs. ${ }^{16}$

The CONEMP states the inclusion of the BP/BPC mission and capability into the CRWs will be additive and will not degrade or impact current CRF missions. The Air Force Global Partnership Strategy enhances Air Force activities in the Building Partnerships core competency and provides guidance for the Air Force and components to develop Global Partnerships. ${ }^{17}$ The AFGPS forms the centerpiece for the individual country pages in the USAF Campaign Support Plan. The country pages provide a snapshot of programs and activities within each country, as well as near-, mid-, and long-term goals to achieve Air Force, Department of Defense, and national level objectives. ${ }^{18}$ 


\section{Air Force and Air Mobility Command Objectives for BP/BPC}

The AF BP CONEMP states that the Air Force engages partner nations, at all levels, whenever and wherever the national priorities dictate and opportunities allow. ${ }^{19}$ The U.S. Air Force will partner with other nations' air forces to build their capability and capacity. In addition to equipment, the training, advice, and assistance provided contribute directly to the stability and security of partners and support mutual national objectives. U.S. activities can simply generate goodwill in a country, which often builds trust, and can result in access and influence. ${ }^{20}$

Additionally, Air Force Doctrine Document 3-20 further defines Building Partnership Capacity as focused unified actions by Airmen to develop the capability and capacity of partner forces and their supporting institutions to achieve common objectives. The AMC BP CONEMP stipulates Building Partner Capacity concentrates on foreign partner capabilities, while Building Partnerships focuses on U.S. Military capabilities to execute a broad range of activities in support of strategy. The CONEMP continues that by building capability and capacity for our global partners, the United States can preclude the necessity of using its own forces to provide the sole means of security for and within partner nations. Increasing partner capability and capacity allows them to defend their own territory, expand the rule of law and governance, and provide support in coalition operations, when appropriate..$^{21}$

The Air Force derived the following four ends from the DoD 2006 BPC Roadmap to better organize, train, and equip its forces to address the importance of building partnerships and supporting Combatant Commander objectives: 1) establish, sustain, and expand Global Partnerships that are mutually beneficial; 2) provide global partners the capability and capacity necessary to provide for their own national security; 3) 
establish the capacity to train, advise, and assist foreign air forces, while conducting partnership activities using U.S. Air Force Airmen with the appropriate language and cultural skills; and 4) develop and enhance partnership capabilities to ensure interoperability, integration, and interdependence. ${ }^{22}$

The BP mission of AMC is to conduct operations that will train, advise, and assist partners in the development of an Air Mobility System (AMS) ${ }^{23}$ Training partner nations in air mobility may increase their capacity to govern through presence and persistence in otherwise inaccessible regions of the country, and by physically extending the reach of public policy and information programs. ${ }^{24}$ Air mobility provides partner nations a means of air transportation to access remote or ungoverned regions and deliver resources and personnel to address a variety of issues. According to the AMC CONEMP, the AMS consists of three basic components for the partner nation: airlift operations, air mobility support system, and the skill sets for expeditionary Agile Combat Support (ACS) centered on air operations. The LiMA provides a low-cost, easily operated and maintained platform to execute airlift operations for the partner nation. The air mobility support system provides the core functions of airlift command and control, aerial port, and maintenance needed to execute efficient aircraft and cargo operations. The third part of the AMS triad, ACS, produces the effects necessary to create, prepare, employ, sustain, and protect partner nation operations through the functions of airfield operations, civil engineering, logistics readiness, communications, security, and health services. AMC will advise and assist partner nations in establishing and/or further developing these basic airlift operations components. Currently, Air Force Contingency Response Groups (CRGs) and Wings (CRWs) have air mobility 
support system and ACS capabilities inherent in their Global Reach Laydown and air base opening missions. ${ }^{25}$

The organization of the AMC CRWs will evolve from their FY2010 reorganized state to accommodate the growth of the wing's BP/BPC mission. Currently, each CRW consists of two CRGs and a Contingency Operations Support Group (COSG).

Eventually, the CRW will add a Mobility Advisory Group (MAG) with two imbedded squadrons, the Mobility Advisory Squadron (MAS) and the Mobility Support Advisory Squadron (MSAS). As the names suggest, the MAS will house the mobility Air Advisors and LiMA operations, while air mobility support system and ACS personnel comprise the MSAS. Figure 1 shows the evolution of the CRWs with the addition of the MAG after the LiMA contract decision.

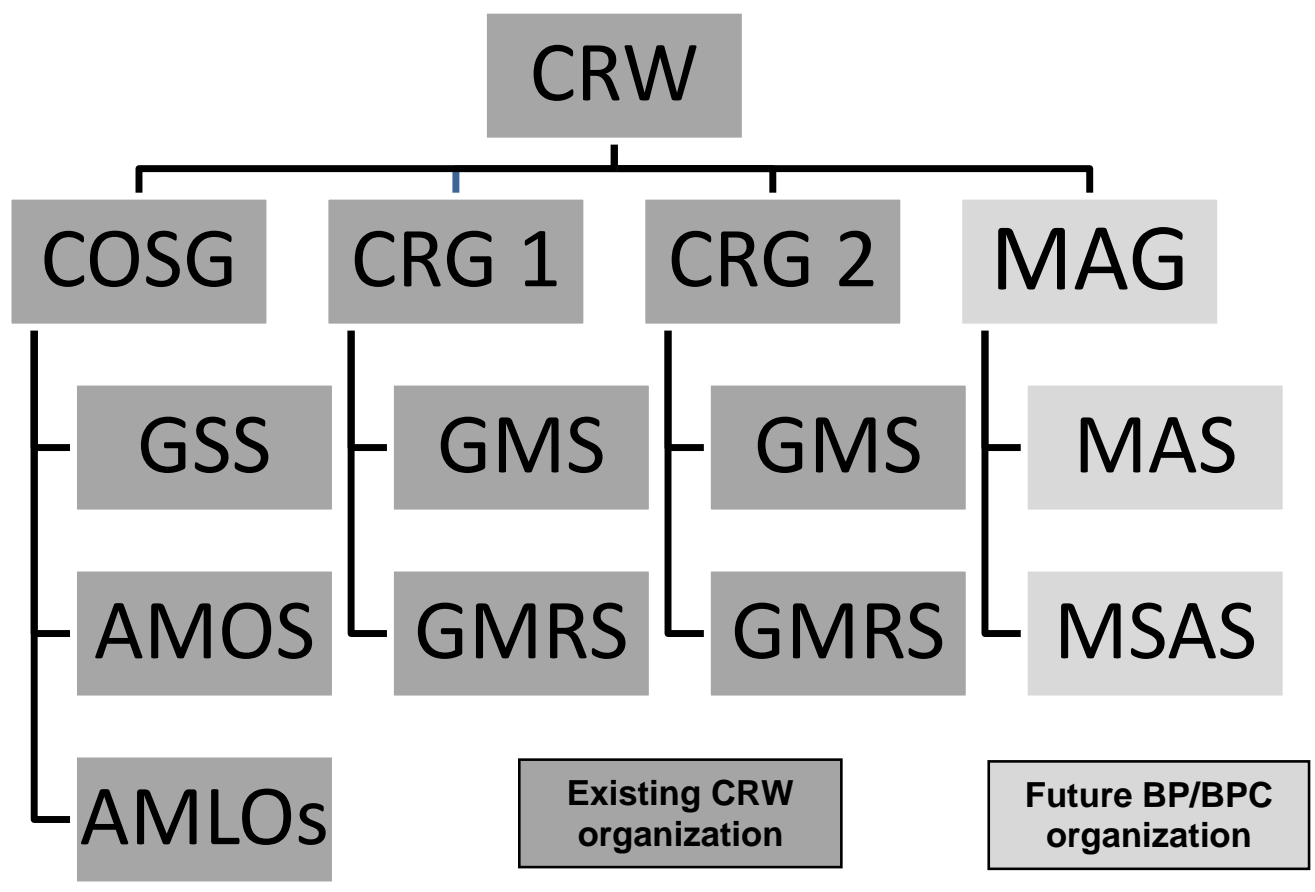

Figure 1. Typical AMC CRW Organizational Structure with BP mission 


\section{Funding the AMC BP/BPC Program}

Geographic Combatant Commands will rely on Air Mobility Command to execute a portion of their Theater Security Cooperation Plans. Each theater and even individual partner nations will have varied requirements and opportunities for partnership and capacity building paid by a multitude of security cooperation funding streams. Initially and for the next five years, there will be only one MAG with 15 LiMAs to execute the Air Force's mobility BPC core function. America's security cooperation priorities and supporting budgets will need resolution between the GCCs, HAF, and HQ AMC.

The U.S. Departments of Defense and State (DoS) execute multiple programs to build partnerships with countries for foreign internal defense. The foundation for Executive Branch action to build partnerships with foreign countries lies in the National Security Strategy and in United States Code Title 22 - Foreign Relations and Intercourse (USC Title 22). The U.S. Congress granted oversight of all international security assistance and foreign policy development to the State Department through USC Title 22. Current departmental and agency efforts furthering the President's strategy of global engagement follow along department funding and "stovepipes" through traditional State Department Security Assistance programs or through The Fiscal Year 2006 National Defense Authorization Act Sections 1206 and 1207 provisions for stabilization and counter-terrorism operations. DOD funding may be used annually to equip, supply, and train a foreign military force to conduct counter-terrorism operations or participate in or support military and stability operations in which U.S. forces are participating. ${ }^{26}$ The BPC Roadmap states, "During the Cold War the legal authorities for military action, intelligence, foreign military assistance and cooperation 
with foreign police and security services were separately defined and segregated from each other." ${ }^{27}$ The roadmap continues, "Today, there is a need for U.S. forces to transition rapidly between these types of authorities in an agile and flexible manner, to meet the challenges of the 21 st century." ${ }^{28}$

The U.S. military engages in security assistance and stabilization and reconstruction efforts that are largely focused on kinetic conflict execution or postconflict recovery. But with the creation of U.S. Africa Command (USAFRICOM) and increased narco-trafficking in U.S. Southern Command (USSOUTHCOM), Combatant Commanders continue to expand partnership efforts to shift effort from kinetic operations to conflict prevention. Commander, USAFRICOM, reported to both the Senate and House Armed Services Committees that the authorities and programs we currently use for building partner capacity are essential and requested continued support in the following areas: 1) full support of the President's budget request for the global train and equip program; 2) support of the Department of State's request for programs in Africa; and 3) support of the Combatant Commander's Initiative Fund, with increased flexibility for foreign military education and training activities. ${ }^{29}$ Additionally, Commander, USSOUTHCOM, articulated the same perspective in his posture statement to Congress by stating, "It is imperative we remain capable of executing our plans, while still engaging throughout the region at the appropriate levels: building, complementing, or enhancing, as appropriate, partner capability and capacity; improving international and interagency cooperation; and fostering both security and stability." ${ }^{30}$ 
The GCCs and U.S. National Guard units already participate in BP and BPC efforts. For example, one of Air Forces Africa's (AFAFRICA) key programs is the Air Domain Safety and Security (ADSS) program, a three-tiered program designed to capitalize on "natural air linkages" where U.S. Air Force programs and capabilities can contribute to increasing capacity within the military and civil aviation programs on the African continent. ${ }^{31}$ ADSS is a long-term Air Force program of record with FY2010 funding of $\$ 2.6$ million with growth projected to $\$ 3.1$ million in Fiscal Year $2011 .^{32}$ AFAFRICA expanded ADSS significantly in 2010 , by utilizing general purpose air forces and working together with U.S. Government agencies (i.e. Federal Aviation Administration, Transportation Safety Administration) and other partners to develop African capacity to provide regional air safety and security solutions to the civil and military air domains. Discussions with Rwanda, Uganda, Nigeria, and Ghana are underway, and will lay the foundation for a common regional air picture. ${ }^{33}$ By offering training, aircraft maintenance advice, and humanitarian aid airlift, among other things, AFAFRICA will help strengthen these relationships throughout the continent and offer a helping hand to build up what is currently a disparate and desperate air domain. ${ }^{34}$ Also, the National Guard Bureau sponsors the State Partnership Program (SPP) that links or partners a state's National Guard units with an individual country to build trust and relationships by leveraging the citizen soldier and airman expertise in both military and civilian skills. This being said, Theater Security Cooperation Plans or "Phase 0" operations plans and the Air Force Security Cooperation Plan have not been updated to reflect the arrival and utilization of AMC's new BP/BPC capability to prevent conflict or overlap with current programs. 


\section{Authority and Appropriations for BP}

Commander, USAFRICOM, states sustaining long-term security cooperation programs and activities in Africa requires flexible, multiyear authorities ${ }^{35}$ Existing authorities are designed to support the conduct of individual short-term activities or long-term programs, but do not support the transition from the former to the latter. ${ }^{36}$ They are also insufficiently responsive to changing conditions, such as when train and equip efforts initiated in response to emergent threats highlight the need for long-term capacity building. ${ }^{37}$ There are approximately 35 authorities and appropriations for the U.S. Air Force to perform BP and BPC activities. ${ }^{38}$ BP and BPC vary by partner nation, the type of activities being performed, and the forces involved, the missions being performed, the yearly defense appropriations acts, and other variables. Given this complex array of authorities, GCC and component planners should seek financial and legal coordination early to ensure legal and fiscal authority exists to execute the BP or BPC missions. ${ }^{39}$ In the interest of expediting and greater utilization of funding for counter-terrorism security assistance, Congress enacted Section 1206 of The Fiscal Year 2006 National Defense Authorization Act. This section, along with other provisions under the Security Assistance banner, partially fragmented the execution authority for security assistance. The mine field of funding lines and legalities may distract and delay initial BP activities and must be aggressively addressed by HQ AMC.

\section{$\underline{\text { Risks and Roadblocks to Success }}$}

The Department of Defense redefined its military strategy to meet the challenges of tomorrow while predicting manpower and funding reductions. Newly developed programs in a resource-constrained environment inherently have risk associated with their implementation. The Air Force and Air Mobility Command implemented the 
mobility BP program with certain risks and roadblocks in the face of future budget cuts, by implementing the BP program incrementally, handicapped by manpower specialty retention, and continued weak personnel policy enforcement.

With the reality of the U.S. national debt and economy causing potentially shrinking future Defense Department budgets, the Air Force cautiously moves forward with the mobility BP program with little hope of expansion. In a roundtable with reporters before a speech at Fort Leavenworth, Defense Secretary Gates stated pressure on the Pentagon budget from the economic downturn and a desire to trim deficits would lead the government to be more selective in future overseas military operations. ${ }^{40}$ TechAmerica, a foundation representing over 1200 defense industry companies, conducted a 2010-2020 Defense Department budget study in 2010 and predicted war supplements will shrink the budget due to Iraq and Afghanistan drawing down as well as shrinking base budget due to deficit pressure. ${ }^{41}$ The foundation believes the Department will focus the budget on ground forces (Army and Marine Corps) for Irregular Warfare and Defense Security Cooperation Agency (DoD's focal point for Security Cooperation) programs, leaving the Air Force and Navy to absorb the reductions. ${ }^{42}$ Additionally, TechAmerica claims Research and Development, as well as procurement, will take the largest cuts. ${ }^{43}$ Confirming TechAmerica's budget predictions, the National Defense Budget Estimates for FY2011 depict a 15 percent reduction to FY2015 procurement by almost $\$ 20$ billion to a total of $\$ 117.5$ billion, slightly below the average for the past ten years including war-related funding when adjusted for inflation. ${ }^{44}$ Additionally, the report shows the Department of Defense increases the International Affairs line item to reflect an adjustment for inflation only. ${ }^{45}$ 
As General Schwartz directed, the Air Force is taking a stepping stone approach to the MAF BP program. It has programmed aircraft and manning for only one Mobility Advisory Group at one CRW. ${ }^{46}$ Additionally, not all manpower positions will be funded. Of the two squadrons within a MAG, only 44 of 84 manpower positions will be funded, with the remaining awaiting emerging mission demand realization. ${ }^{47}$ Of the 44 funded positions, Headquarters Air Force will source and fund 30 positions, as the CRW reorganization yielded 14 funded manpower positions. ${ }^{48}$

The Air Staff has not sourced or programmed the aircrew and maintainers for the second squadron within the MAG that will execute LiMA training; however, Headquarters AMC predicts approximately 110 positions in the MAG. ${ }^{49}$ Not mentioned in the Air Force CONEMP, the AMC CONEMP addresses a possible expansion to 60 LiMAs residing in both $\mathrm{CR}$ wings and at the CRGs under the European and Pacific Commands. The Air Force FY11 budget overview details a funding request for research, development, and procurement of 15 LiMAs with no further submission for procurement in the PB 2011 to FY15 beyond the 15 aircraft. $^{50}$ However, unit stand-up and continued Operations and Maintenance costs are projected to FY15. Showing its commitment to the mobility BP program and likelihood of funding, the Air Force placed $\mathrm{BP}$ and BPC programs within its number two umbrella priority. ${ }^{51}$

Manning the new billets in the MSAS, funded or unfunded, will pose a challenge to the Air Force and AMC. For example, cornerstone to the ACS piece is civil engineering pavements specialty trained and qualified personnel. Air Force officials expect the Air Force will face a critical retention environment in 2010 in some of the larger career groups-particularly civil engineers. ${ }^{52}$ Lt Gen Richard Newton III, Air 
Force Deputy Chief of Staff, Manpower and Personnel, testified to the House Armed Service Committee, "We project a need in FY11 for additional retention in skills such as...Airfield Operations...Civil Engineering...Logistics Readiness...due to personnel shortages in specific [year groups] and high training investment cost." ${ }^{53}$ Confirming this problem, Air Force Civil Engineering Support Agency reports a Pavements Engineering program challenge will be to maintain a pool of professional engineers capable of design, quality assurance and evaluation, construction, and repair to meet Air Force requirements. ${ }^{54}$ Aggravating the shortages of key specialties is a manning structure having multiple failure points illustrated by single manpower positions for low density, high demand specialties as Civil Engineering, Logistics, and Airfield Operations Officers.

Currently, Air Mobility Command Instruction 10-202 Volume 4, Expeditionary Air Mobility Support Operations, states CRW personnel must be worldwide deployable. ${ }^{55}$ The instruction also states personnel with a physical profile that would prevent or exempt them from worldwide mobility requirements will not be assigned to the CRW. Personnel who cannot deploy and perform required tasks due to permanent or longterm physical limitations or restrictions will be considered for reassignment or separation. Personnel who cannot meet mobility requirements or who become nondeployable and are already assigned will be identified to the installation, AMC, or AFPC functional manager for appropriate actions, to include reassignment. The AMC BP CONEMP echoes this same verbiage. CRW units are small in number with many Air Force Specialty Code (AFSC) positions represented by a single manpower position. Adding to this tenuous fact is the CRWs' readiness posture stipulated in its designed 
operational capability for possible unit deployment within 12 hours of notification. ${ }^{56}$ Past track record shows $\mathrm{HQ} A M C$ and $\mathrm{CRWs}$ have been unsuccessful in their ability to mitigate the impact of non-deployable members and enforce this policy to fill critical CRG manpower positions due to personnel tempo, long-term deployment requirements, and shortages in certain AFSC levels. ${ }^{57}$ In anticipation and realization of current manning issues, the AF CONEMP and the AMC CONEMP discuss augmentation from other CRGs, host installation units, the 820th Base Defense Group, and Prime Base Engineer Emergency Force (PRIME BEEF) units. ${ }^{58}$ Both CONEMPs recommend units develop Memorandums of Agreement between these units to facilitate augmentation. $\underline{\text { Insights }}$

The successful employment of Air Mobility Command's BPC forces may be in jeopardy. The Air Force and Air Mobility Command will not have enough money, skilled manpower, or assets to meet the needs of the Combatant Commands. In its 2009 observation and recommendations report, the IWTT concluded after visits and discussions with all the Combatant Commanders (CCDRs) that the Air Force was meeting its goals in both Afghanistan and Iraq; however, "the USAF is not meeting all CCDR demand for aviation for IW, BPC, and AA [Air Advisor] capabilities." ${ }^{59}$ During FY2010, the Air Force restructured and reduced CR forces as determined by the CR Requirements Review. Cuts in the Defense Department's budget in Research, Development, and Procurement will freeze AMC's program at its initial level until possibly 2020. The shift in National Security Strategy to building partnerships will place greater demand for air mobility BP/BPC activities beyond AMC's initial MAG. The shortage of capability will require augmentation of certain high demand AFSCs within the MAG by CR personnel and by personnel from other than CRW/CRG units like 
PRIME BEEF units or the 820th Base Defense Group. ${ }^{60}$ Exasperating the stress on the MAG due to global requirements, AMC traditionally has been unable to fully fill various specialties within the CRWs due to low manning averages in critical AFSCs.

\section{$\underline{\text { Recommendations }}$}

Building lasting partnerships and strengthening partner nations' ability to be selfsufficient is key to our national security strategy. The Air Force and Air Mobility Command recognize the mobility BP program will evolve and improve over a long period of time. That said, both headquarters elements can take some high impact measures to ensure the mobility BP program stand-up is not encumbered or plagued by the same challenges experienced by the establishment of the CRWs and CRGs. Headquarters elements should take action in the areas of stronger personnel policy and higher headquarters coordination to facilitate bringing the new program to full operational capability.

Recruitment and retention challenges of various Air Force specialties, for example Civil Engineering, Airfield Management, and Command and Control, will plague the new MAG. Due to the specialized BP training and operations of the new MAG, recommend HQ Air Force codify mandatory 100 percent personnel fills for the MAG's manpower positions. This action prioritizes manning fills for the Air Force Personnel Center (AFPC) action officers and places the proper attention required to ensure this highly specialized unit is manned appropriately. In addition to 100 percent manning, AMC must provide the CRWs greater leverage to exchange personnel having non-deployable ALCs within the assigned base and with AFPC. Finally, recommend HQ Air Force or Air Mobility Command broker "Command-to-Command Agreements" rather than suggesting the $\mathrm{CRW}$ advocate multiple wing-level Memorandums of 
Agreement with wings and groups. A Command-to-Command Agreement provides greater visibility to the intricacies of augmentation (funding, command relationships, etc) of AMC's BP forces from other Major Commands such as Air Combat Command or Pacific Air Forces PRIME BEEF units.

Recommend HQ Air Force International Affairs (SAF/IA) facilitate inculcating partnership building within AMC by creating "cross-tel" opportunities with Defense Department, National Guard Bureau, and other government organizations currently involved with Partnership and Security Cooperation programs to capitalize on Tactics, Techniques, and Procedures associated with BP and BPC. These "cross-tel" opportunities must include areas such as language skills, culture training, and security cooperation program education. This effort will enable the entire Air Force BP and BPC community to network efficiently while providing the avenue for "newcomers" of BP and BPC programs to rapidly gain competency.

Recommend HQ AMC begin a working relationship with Headquarters Air Force Special Operations Command (AFSOC) to exploit lessons learned from possessing the Air Force's long-standing Combat Air Forces Air Advisor program, resident in the 6th Special Operations Squadron (6 SOS). These lessons learned should include areas of funding, command relationships, and possible economy of effort. While providing "Best Practices" to AMC as its BP program develops, the Air Force BP/BPC community, fostered by $\mathrm{HQ}$ AMC with $\mathrm{HAF}$ and $\mathrm{AFSOC}$, facilitates partnering at the wing and group level between the CRWs and 1st Special Operations Wing, as well as the MAG and 6 SOS. 
Recommend continuing partnering with the U.S. Government interagency community to leverage currently established partnerships, provide efficiencies in building future relationships, and present a unified effort to the partner nation. Both the Departments of Defense and State are moving toward greater interagency cooperation for the building of partnerships. Global contingencies prompt the U.S. Government to respond with a "full" government approach.

Lastly, recommend SAF/IA, in conjunction with $\mathrm{HQ} A M C$, engage component Air Forces to educate the GCCs and country teams on this new capability. Education of the MAF BP and BPC programs and capabilities will enable GCCs to properly update Theater Security Cooperation Plans, providing a "pull" requirement for the capability rather than a "push" from AMC. Additionally, it will facilitate the scheduling of BP/BPC program training to better serve multiple GCC requirements.

\section{$\underline{\text { Conclusion }}$}

The Air Force answers the 2010 National Security Strategy and steps into the 21st Century with a bold but realistic approach to building partnerships and partner capacity to position partner nations for security and humanitarian operations. Through solid research and reorganization, Headquarters Air Force and Air Mobility Command developed a concept with the potential to provide a relatively low cost, sustainable air mobility solution to the geographic combatant commands for partner nations lacking the capability to reach their hinterlands. However, there are many resource implications and challenges that need to be overcome to ensure its success. The paper's five broad recommendations related to manpower, creation of a BP/BPC community, and particularly the education of the geographic combatant commands on the new AMC BP/BPC scheme need implementation. Otherwise Air Mobility Command runs the risk 
of its new building partnership and building partnership capacity program getting off to a sluggish start or, even worse, losing credibility with Headquarters Air Force and the geographic combatant commands before the program gets firmly established and productive.

\section{Endnotes}

${ }^{1}$ George W. Bush, National Security Strategy (Washington DC: The White House, March 2006), 1.

${ }^{2}$ Ibid.

${ }^{3}$ Barak H. Obama, National Security Strategy (Washington DC: The White House, May 2010), 3.

${ }^{4}$ Ibid, 11.

${ }^{5}$ U.S. Department of Defense, QDR Execution Roadmap Building Partnership Capacity (Washington DC: The Department of Defense, May 2006), 6.

${ }^{6}$ U.S. Air Force, Building Partnerships, Air Force Doctrine Document 3-20 (Maxwell AFB, AL: LeMay Center for Doctrine Development and Education, Draft), 16.

${ }^{7}$ Hillary R. Clinton, "Leading Through Civilian Power," Foreign Affairs 89, no 6 (November/December 2010):22.

${ }^{8}$ Author served as a U.S. Air Force Contingency Response Group Operations Officer responsible for civil-mil airport operations at Port-au-Prince International Airport from 14 Jan 20 Feb 2010 during Haitian earthquake crisis. Author's duties included coordination with the stated government departments. More departments may have been supporting the entire U.S. Government effort from other locations.

${ }^{9}$ Ioan Grillo, "With Haiti government crippled, bodies rot in streets," GlobalPost, January 15, 2010, http://www.globalpost.com/dispatch/the-americas/100115/haitian-governmentearthquake-cleanup (accessed November 3, 2010).

${ }^{10}$ U.S. Department of Defense, QDR Execution Roadmap Building Partnership Capacity, 3.

${ }^{11}$ Ibid, I.

${ }^{12}$ Michael G. Mullen, National Military Strategy of the United States of America 2011: Redefining America's Military Leadership (Washington DC: U.S. Joint Chiefs of Staff, February 2011), i. 
${ }^{13}$ U.S. Air Combat Command and Air Mobility Command, Light Attack/Armed Reconnaissance \& Light Mobility Aircraft Capability Based Assessment, (Langley AFB, VA: U.S. Air Mobility Command, August 2009), iii.

${ }^{14}$ U.S. Air Mobility Command, Air Mobility System Building Partnerships Concept of Employment (Scott AFB IL: U.S. Air Mobility Command, August 2010), 73.

${ }^{15}$ U.S. Air Force, FY 2011 Budget Review (Washington DC: The Department of the Air Force), http://www.saffm.hq.af.mil/shared/media/document/AFD-100129-082.pdf (accessed December 11, 2010).

${ }^{16}$ U.S. Air Force, Institutionalizing Building Partnerships into Contingency Response Forces (Washington DC: The Department of the Air Force, April 2010), 2.

${ }^{17}$ Bruce S. Lemkin, "Global Partnerships - Strategies," AIR FORCE Magazine Online 5 February 2009, http://www.airforce-magazine.com/SiteCollectionDocuments/Reports/2009/ February\%202009/Day06/020509lemkin.pdf (accessed February 10, 2010).

18 Ibid.

${ }^{19}$ U.S. Air Mobility Command, Air Mobility System Building Partnerships Concept of Employment, 12.

${ }^{20}$ Ibid.

${ }^{21}$ lbid, 13.

${ }^{22}$ U.S. Air Force, Global Partnership Strategy: Building Partnerships for the $21^{\text {st }}$ Century, (Washington DC: The Department of the Air Force), December 2008

${ }^{23}$ U.S. Air Mobility Command, Air Mobility System Building Partnerships Concept of Employment, 15.

24 lbid, 13.

${ }^{25}$ U.S. Air Force, Contingency Response Group Operational Concept, (Washington DC: The Department of the Air Force, April 2004), 19.

${ }^{26}$ Defense Institute of Security Assistance Management, The Management of Security Assistance, 29th ed. (Wright-Patterson AFB, OH: Defense Institute of Security Assistance Management, January 2010), 1-9.

${ }^{27}$ U.S. Department of Defense, QDR Execution Roadmap Building Partnership Capacity, 6.

${ }^{28}$ Ibid.

${ }^{29}$ William E. Ward, Partnership Peace Stability: 2010 Posture Statement United States Africa Command, Posture Statement presented to the 111th Cong. (Stuttgart, Germany: Kelly Barracks, March 9-10, 2010), 35. 
${ }^{30}$ Douglas M. Fraser, Posture Statement of General Douglas M. Fraser, United States Air Force, Commander, United States Southern Command, Posture Statement presented to the 111th Cong., (Miami FL: Headquarters U.S. Southern Command, March 11, 2010), 15.

${ }^{31}$ Ward, Partnership Peace Stability, 33.

32 Ibid.

${ }^{33}$ Ibid.

${ }^{34}$ Maj. Gen. Ronald R. "Ron" Ladnier Jr, in a U.S. Air Forces AFRICOM public statement release by Air University Public Affairs (Maxwell AFB, AL: Air Force News Service, March 13, 2009).

${ }^{35}$ Ward, Partnership Peace Stability, 35.

${ }^{36}$ Ibid.

${ }^{37}$ Ibid.

${ }^{38}$ LeMay Center for Doctrine Development and Education, USAF Security Cooperation Handbook (Maxwell AFB, AL: LeMay Center for Doctrine Development and Education, Draft), 22-29.

${ }^{39}$ U.S. Air Mobility Command, Air Mobility System Building Partnerships Concept of Employment, 14.

${ }^{40}$ Julian E. Barnes, "Gates seeks big cuts in military spending," Los Angeles Times Tribune Washington Bureau, May 09, 2010, http://articles.latimes.com/2010/may/09/nation/la-na-gates20100509 (accessed November 3, 2010).

41 John T. Bennett, "Foundation: Base DoD Budget of \$488B by 2016," DefenseNews 19 Oct 2010, http://www.defensenews.com/story.php?i=4934646, (accessed November 3, 2010). DefenseNews reports TechAmerica study published Budget prediction for 2010-2020. TechAmerica is foundation representing over 1200 defense industry companies to help improve their bottomline. To create the report, TechAmerica and its research arm, TechAmerica Foundation, convened a 31-member commission drawn from industry, academia, and government.

${ }^{42}$ Ibid.

${ }^{43}$ lbid.

44 U.S. Department of Defense, National Defense Budget Estimates for FY2011

(Washington DC: The Department of Defense, February 2010), Table 1-4, 9.

45 Ibid, Table 1-8, 13.

${ }^{46}$ U.S. Air Mobility Command, Air Mobility System Building Partnerships Concept of Employment, 25, 70-71, 75. 
${ }^{47}$ lbid, 70-71.

${ }^{48}$ lbid.

${ }^{49}$ HQ Air Mobility Command A8XP, "Building Partnership Forces (BPF) Timeline Update," briefing slide, Scott AFB, IL, HQ Air Mobility Command, August 2010.

${ }^{50}$ U.S Air Force, FY 2011 Budget Review (Washington DC: The Department of the Air Force), http://www.saffm.hq.af.mil/shared/media/document/AFD-100129-082.pdf (accessed December 11, 2010), 4.

${ }^{51}$ Ibid, 37.

52 Tom Philpott, "Sustain and Retain,” AIR FORCE Magazine 92, no 6 (June 2009): 50.

${ }^{53}$ Richard Y. Newton III, "Department of the Air Force Presentation to the Subcommittee on Military Personnel, Committee on Armed Services Unites States House of Representatives: Air Force Military Personnel Legislative Priorities," March 17, 2010, in U.S Army War College Selected Reading AY11, Defense Enterprise Management (Air Service Focused Readings), (Carlisle Barracks, PA: Department of Command, Leadership, and Management, 2011), 46.

${ }^{54}$ Air Force Civil Engineer, Special Edition: Subject Matter Experts 17, special ed 1 (Tyndall AFB FL: U.S. Air Force Civil Engineer Support Center, December 2, 2009), 23.

${ }^{55}$ Air Mobility Command, Expeditionary Air Mobility Support Operations, Air Mobility Command Instruction 10-202 Volume 4 (Scott AFB IL: U.S. Air Mobility Command, December 2009), 29.

${ }^{56}$ Ibid, 30.

${ }^{57}$ Author served as Director of Staff, 621st Contingency Response Wing, responsible for wing officer management, including Civil Engineering, Logistics Readiness, and Airfield Operations Officers, to the commander. Data is sourced from the years 2006-2010.

${ }^{58}$ U.S. Air Mobility Command, Air Mobility System Building Partnerships Concept of Employment, 5-6.

${ }^{59}$ U.S. Air Force, Irregular Warfare Tiger Team Observations and Recommendations, (Washington DC: The Department of the Air Force, May 2009), 4.

${ }^{60}$ U.S Air Force, Building Partnerships, Air Force Doctrine Document 3-20, 5-6. 